\title{
The Relationship among Consumer Attributions, Consumer Skepticism, and Perceived Corporate Social Responsibility in Taiwan
}

\author{
Bryan H. Chen ${ }^{1} \&$ Wan-Ching Chiu ${ }^{1}$ \\ ${ }^{1}$ Department of Finance, National Changhua University of Education, Taiwan \\ Correspondence: Bryan H. Chen, National Changhua University of Education, Changhua City, Taiwan.
}

Received: December 13, 2017 Accepted: January 6, 2018 Online Published: February 3, 2018

doi:10.5539/ijms.v10n1p29 URL: https://doi.org/10.5539/ijms.v10n1p29

\begin{abstract}
This study aimed to explore the relationship of consumer attributions, consumer skepticism toward CSR, and its influence on perceived CSR in Taiwan. Final usable questionnaires received from 659 respondents to reach the return rate of $78.8 \%$. After confirming reliability and validity of survey questionnaire, the structural equation modeling was used for tests the model. Results were summarized as follows: (a) value-driven motives are negatively related to CSR skepticism, which was significant; however, the relationship was positive association. (b) CSR skepticism is positively related to ethical responsibility, which was supported. (c) CSR skepticism is negatively related to philanthropic responsibility, which was significant; however, the relationship was positive association. This study may make a positive contribution for business managers to understand the expectations of consumers in Taiwan.
\end{abstract}

Keywords: corporate social responsibility, consumer attributions, consumer skepticism, perceived CSR

\section{Introduction}

The issue of corporate social responsibility (CSR) spread increasingly not only on corporate agenda but in academic research field. Previous relevant studies for CSR emphasize different factors from consumers (Grappi, Romani, \& Bagozzi, 2013; Lee, Park, Rapert, \& Newman, 2012), investors (Groening \& Kanuri, 2013), employees (Lee, Park, \& Lee, 2012), marketing strategies (Achabou \& Dekhili, 2013; Perks, Farache, Shukla, \& Berry, 2013), and company environmental performance and consumer intentions (Grimmer \& Bingham, 2013). Firms engage CSR activities would gain supports from stakeholders (Maignan, \& Ferrell, 2004), leverage finance benefits, increase economic performance to achieve win-win relationship between corporations and stakeholders (Carroll \& Shabana, 2010).

Firms embark on CSR activities through connecting media in order to strengthen reputation, build positive image, and augment international visibility with the purposes of attracting consumers, increasing consumer trust, and promoting repurchase rate (Varadarajan \& Menon, 1988). Nowadays, corporations perceive the importance of CSR, combine media, and engage CSR activities in order to influence consumer behaviors, which is cause-related marketing (CRM). CRM is a CSR initiative which joints "being good" behavior and business marketing (Anuar \& Mohamad, 2012).

The target of CRM activities is consumers. The purposes of CRM are to draw consumers' attention toward companies' actions, to increase financial performance, to augment consumers' positive perception, and to influence consumers' options. Consumer perceptions crucially affect companies' actions of CSR activities; hence, consumer perceptions serve as a measurement of CSR (Stanaland, Lwin, \& Murphy, 2011), and companies undertake CSR activities are motived by consumer stance.

Consumers expect a company to take its social responsible. Companies realize that CSR connects consumer need and leads to excellent performance as well as launches sustainable business initiatives. Hence, companies draw from Carroll's (1979) principles on CSR that emphasize four types of corporate social responsibilities comprise of economic, legal, ethical, and philanthropic. In the last decades corporations actively embark on CSR activities, including ensuring stakeholder's rights, concerning society, joining community activities, donating charity, and protecting environment (Peloza \& Shang, 2011). CSR is often linked with positive conception, but corporate social irresponsibility (CSI) occurs deliberately or unconsciously in succession. The CSI incidents cause consumers' negative and mistrust conception. Most people link CSR with charity, which means doing good, but 
ignore companies have the obligations to keep stakeholders away from harm, which means avoiding bad. CSI is divided into two forms, which are intentional and unintentional CSI. Intentional CSI means companies act deliberately because of profits. Unintentional CSI could be explained the companies act recklessly to harm others, and distinguished into two forms, external and internal factor. Such earthquakes can be an external factor to damage consumers while real estate companies neglect the crisis in seismic zone, and such internal factor can be the damage because of unconscious mistakes (Lin-Hi \& Muller, 2013). Multinational corporations could not avoid unforeseen accident due to multicultural problems, however, unintentional CSI could not be forgiven and neglected (Strike, Gao, \& Bansal, 2006).

Consumer perceptions would be directly affected by the proportion of firm's donation (Folse, Neidrich, \& Grau, 2010). Forehand \& Grier (2003) specify that consumers tend to give negative evaluation when they doubt corporations engage into CSR for self-benefits, not public-benefits. Compared with CSR, consumers pay more attention on negative information about CSI, which would be discussed by word-of-mouth for a long while (Wagner, Bicen, \& Hall, 2008).

The framework of attribute theory elaborate consumers would be skeptical when observing CSR activities and CSI actions. In other words, consumers might perceive CSR activities and their perceptions affect their subsequent attitudes by different attribute motives. Skarmeas \& Leonidou's (2013) work investigates how consumer skepticism toward CSR develops and its influence on equity, resilience to negative information, word-of-mouth, and customer orientation. The previous study focused on consumer-related outcome; however, the consumer skepticism toward CSR activities, which in turn impact perceptions of CSR was not explored. This study aims at investigating whether consumer skepticism toward CSR influence their attitudes toward CSR core value.

Most previous studies which discuss CSR with attribution theory focused on consumer loyalty, trust (Vlachos et al., 2009), and purchase intention (Ellen et al., 2006). Due to the lack of literature reporting consumer skepticism toward CSR via attribution theory, this study provided insight in to the issue.

Strike et al. (2006) indicate that CSR presents positive value, and CSI links with negative value. As a consequence, corporations attempted to engage CSR activities and reported their sustainable development. However, CSI actions occurred frequently, and corporations argue that current actions are unintentional CSI. Whether corporations act unintentionally to cover intentional CSI, or they engage into CSR activities to overturn consumers' attention? The debate of consumer skepticism toward CSR has spread (Murphy \& Schlegelmilch, 2013). Companies' CSI actions affect consumer perceptions, which in turn increase consumer skepticism toward CSR activities. Hence, the purpose of this study is to develop and test a model that investigates consumer attribution affect the form on consumer skepticism toward CSR. Furthermore, this study contributes to consumer skepticism toward CSR activities, and its influence on perceived CSR. Thus, this study builds a framework on previous literature by exploring the relationships of consumer attribution, consumer skepticism, and perceived CSR under a virtual scenario situation.

\section{Literature Review}

\subsection{Skepticism toward CSR}

Skepticism could be explained the sense of disbelief (Obermiller \& Spangenberg, 1998), or the individual concept of distrust, cynicism, or suspicion (Forehand \& Grier, 2003). Consumer skepticism defined as individuals doubt that the firm's motives are self-serving but rather volunteering actions (Anuar \& Mohamad, 2012). Obermiller \& Spangenberg (1998) assume that consumer skepticism is an individual trait, which leads the dislike or distrust attitude toward advertising; meanwhile, they discussed that highly skeptical consumers may be more skeptical firms' actions, and the less skeptical consumer more likely to believe.

Webb \& Mohr's (1998) work on consumer skepticism discusses both consumer perception toward CRM, and whether CRM offers influence consumer behavior and attitude. They demonstrated that consumers are doubtful about CSR activities, and consumers' concerns centered around four situations: (a) distrust of whether corporations actually donate the amount they promised; (b) the details of their contribution; (c) the donated amount does not match financial gain; and (d) CRM campaigns influence consumers to purchase products which are overpriced, or not needed. Yeh's (2003) study examines the moderating effects of consumers' skepticism toward advertising and found consumers' skeptical attitude actually influences advertising effects. Forehand \& Grier's (2003) work on consumer skepticism regarding a firm's motives depictes that consumers' perception toward a firm is driven by trust that the firm engage social activities for its public-serving motives but by distrust due to its self-serving motives; in other words, firms gain a lot of profit but give less feedback to society is the reason which consumers suspect. Anuar \& Mohamad (2012) examine the influence of consumer skepticism on 
attitude toward CRM and evaluation of CRM and suggest corporations might offer direct communication to consumers to diminish skepticism. When consumers tend to doubt companies' actions; that is, that would influence consumer subsequent behaviors, such as purchase intention, loyalty, and trust. In addition, consumers would attempt to resist the products which made from the irresponsible companies. Consumers who learn negative corporate actions would induce consumer emotions of contempt, anger, and disgust and turn these emotions to the actions of word-of-mouth to protest irresponsible corporations (Grappi et al., 2013). Becker-Olsen et al. (2006) found that consumers might blame corporate behaviors, doubt its motives, and give negative evaluations to the corporations which engage CSR activities by self-serving motives; meanwhile, consumers are against to purchase the products and be able to use replacement. Consumers expect corporations engage CSR activities by public-serving motives and supervise whether corporations act social irresponsibility with skepticism (Murphy \& Schlegelmilch, 2013). CSR is an umbrella for corporations to raise consumer positive attitude, reduce risk, and avoid consumer boycott. Consumer skepticism toward CSR is increasing, and therefore long-term brands would be harmed to great damage, and corporate efforts finally become bubbles. Hence, there is a pragmatic need for scholars and executives to recognize consumer skepticism, avoid consumer punishment behavior (Sweetin, Knowles, Summey, \& McQueen, 2013), maintain valuable reputation, and promise sustainable development.

\subsection{Consumer Attribution Theory}

Attribution theory explained how people infer from self-concept and subsequently affect their attitude and behavior (Heider, 1958). Attributions are what people perceive the reason behind their behavior or the events they observe (Bitner, 1990). Attribution is made via observing a single individual's behavior toward a stimulus object at one point in time. Hence, psychologists inferred that individual's perception would act on the stimulus object rather than the object itself (Sparkman \& Locander, 1980). Forehand \& Grier (2003) clarify that attribution theory is the process that consumers evaluate marketer motives and how these motives influence consumer subsequent attitude and behavior. Consumers highly concern and evaluate corporate engaging social responsible activities; thus, corporations effort to increase its reputation, image (Lai, Chiu, Yang, \& Pai, 2010), consumer loyalty, trust (Martinez \& Rodriguez del Bosque, 2013), consumer behavior (Becker-Olsen et al., 2006), consumer satisfaction (Hsu, 2011) by engaging CSR.

Sparkman \& Locander's (1980) study uses Kelley's (1967) four dimensions of attribution variables to prove consumer perception would be influenced by advertising. Previous studies investigated service failures utilized attribution theory. Bitner's (1990) work focuses on consumer satisfaction, service marketing, and attribution theory to evaluate service and demonstrated consumers not only observe service firm but assess employee responses in a service context. Hung et al. (2012) depict the situation of service failures based on three dimensions of attribution theory and found controllable and stable are potential factors which consumers are unsatisfied with. Consumer attribution toward CSR directly affects consumer trust and behavior (Vlachos et al, 2009), influences purchase intention, and becomes a crucial role to push CSR activities (Ellen et al., 2006). Groza et al. (2011) used attribution theory as a theoretical foundation to examine the CSR initiative influences consumer attribution and these attributions act as a mediator to explain consumers' responses to CSR. Drawing on attribution theory, Skarmeas \& Leonidou (2013) assume egoistic-driven motives and stakeholder-driven motives are positively related to CSR skepticism while values-driven motives and strategic-driven motives are negatively related to CSR skepticism. Kelley (1967) first classified attribution four factors and then divides them into three types: distinctiveness, consistency and consensus. Weiner (1980) elaborates three factors of attribution: locus of control, controllability, and stability. In addition, an internal attribution is caused due to self-conscious while an external attribution is caused due to the events of surrounding environment (Schmitt \& Branscombe, 2002).

Corporate actions are influenced by consumer concerns, and consumer's perception affects corporations on subsequent reactions and behaviors (Stanaland et al., 2011). The literature suggests that consumer attribution theory provides an appropriate framework for understanding consumer skepticism toward CSR (Skarmeas \& Leonidou, 2013). Ellen, Webb, \& Mohr (2006) surveyed consumer's responses and then coded attributions to self-centered motives and other centered motives, and analyzed them into four motives, including ego-driven motives, values-driven motives, strategic-driven motives, and stakeholder-driven motives. Additionally, they examined the relationship between consumer attribution theory and perceived CSR and turned to the facts that consumer attributions response CRM best. Most researchers followed the work of Ellen et al. (2006) to investigate the relationships between consumer's perception and perceived CSR. Hence, consumer attribution is proper to explain how CSR campaigns influence consumer's perception and their subsequent attitude and behavior. The actions which corporations engage CSR activities, attempt to make an image as "good corporate 
citizens", appear their ethics statements, and subsequently increase consumer loyalty and competiveness to construct a win-win situation (Ellen et al., 2006). The focus of this study is on developing and testing the model of consumer attributions, consumer skepticism toward CSR, and perceived CSR in the context of finance students.

Egoistic-driven motives are regarded as beliefs that corporations engage in CSR activities because of benefits and opportunistic motives, which turn into confusing consumer's perception to CSR engagement.

H1. Egoistic-driven motives are positively related to CSR skepticism.

Value-driven motives are regarded as beliefs that corporations engage in CSR activities because of their public-serving, ethical, and moral motives, which mean CSR is an action of sincere concerns.

H2. Value-driven motives are negatively related to CSR skepticism.

Strategic-driven motives are regarded as beliefs that corporations engage in CSR activities because they attempt to increase business benefits and maintain customers, which tend to economic profits rather than ethical concerns.

\section{H3. Strategic-driven motives are positively related to CSR skepticism.}

Stakeholder-driven motives are regarded as beliefs that corporations engage in CSR activities to satisfy the expectations of entire stakeholders. That is, CSR actions are not sincere concerns for society but avoiding negative responses of different stakeholders. Thus, consumers would doubt CSR campaigns serves as avoiding negative punishment.

H4. Stakeholder-driven motives are positively related to CSR skepticism.

\subsection{Perceived Corporate Social Responsibility}

Corporations embrace CSR to relieve the social, environmental, and economical problems, and the purpose is to raise public and stakeholder's benifits (González-Rodríguez, Díaz-Fernández, Pawlak, \& Simonetti, 2012), as well as achieve sustainable development (Coppa \& Sriramesh, 2013). CSR campaigns should not seem as a zero-sum game, but the inter-relationship to reflect social imperatives and business success (Murphy \& Schlegelmilch, 2013). Most business today embrace CSR because people strongly support and require CSR campaigns (Carroll \& Shabana, 2010). Relevant studies showed that recently consumers demand CSR initiatives because CSR is a crucial role to directly influence consumer behavior (Becker-Olsen et al., 2006), being closer to consumers, and meet consumer fit (Lee, Park, Rapert, \& Newman, 2012). A number of previous studies contributed to consumer expectations and perceptions. Matute-Vallejo et al. (2011) explore how consumer's perception toward CSR and price fairness affect consumer evaluation, and found CSR and price fairness positively determine customer loyalty through satisfaction and commitment. Lee et al. (2012) examine the perceived fit of a company's CSR activities with consumers' values, lifestyles, loyalty, and consumer-company identification from consumers' perspective; meanwhile they suggested perceived fit between the firm and CSR activities is a significant factor on consumer response and has positive effect on consumer beliefs, attitude, and intention (Becker-Olsen et al., 2006).

Consumers with high environmental involvement show greater purchase intention for the company of high perceived environmental performance (Grimmer \& Bingham, 2013). Snider, Hill, \& Martin (2003) represent the CSR campaigns of top-50 multinational firms, indicating firms address on their websites regarding CSR would affect consumer purchase intention, and consumers could receive information from the Internet to decide whether increase their purchase behaviors or resist their irresponsible actions. Stanaland et al. (2011) examine CSR from the consumer's perspective, focusing on antecedents and consequences of perceived CSR, and would suggested firms have both sound financial performance and ethics statements would rather engage in CSR activities. In other words, firms which embrace CSR initiatives would improve their brand image as well as consumer trust, and reduce perceived risk to form a virtuous circle of sustainable development.

Consumers observe corporations engage in socially responsible activities, such as involving CRM, philanthropy, environmental protection, community, and donations (Peloza \& Shang, 2011) would reward the corporate brand, but conversely punish their irresponsible actions (Sweetin et al., 2013). Hence, this study focuses on whether consumer skepticism toward CSR and CSI influences perceived CSR. Anuar \& Mohamad (2012) consider the impact of consumer response toward CRM and assumed that less skeptical consumers seemed to have a more favorable attitude toward CRM compare to those who are high skeptical ones. Consumers evaluate firms by observing their motives, which showing public-serving positively affects consumer skepticism toward perceived CSR (Forehand \& Grier, 2013). 
Prior research has suggests that consumers may not be affected their purchase decisions because of consumer's assessment of CSR initiatives, and most consumers consider other conditions, such as price, quality, brand, country of origin, or service rather than CSR (Öberseder, Schlegelmilch, \& Gruber, 2011). According to Carroll's (1991) work, four types of social responsibilities, including economic, legal, ethical, and philanthropic responsibilities, following environmental responsibilities (Peloza \& Shang, 2011), which researchers addressed are assessed in this study. Whether consumers are skeptical about perceived CSR, and what factors of perceived CSR consumers would highly value while consumers do not affected by CSR activities? It is a need to investigate whether consumer skepticism toward CSR would influence the evaluation of CSR or differential from high level of ethical, philanthropic, and environmental responsibilities. This study deeply investigates the possibilities between CSR skepticism and the five factors of CSR. Therefore, the hypotheses are posited as followed. All proposed relationships are depicted in Figure 1.

H5-1. CSR skepticism is negatively related to economic responsibility.

H5-2. CSR skepticism is positively related to legal responsibility.

H5-3. CSR skepticism is positively related to ethical responsibility.

H5-4. CSR skepticism is negatively related to philanthropic responsibility.

H5-5. CSR skepticism is positively related to environmental responsibility.

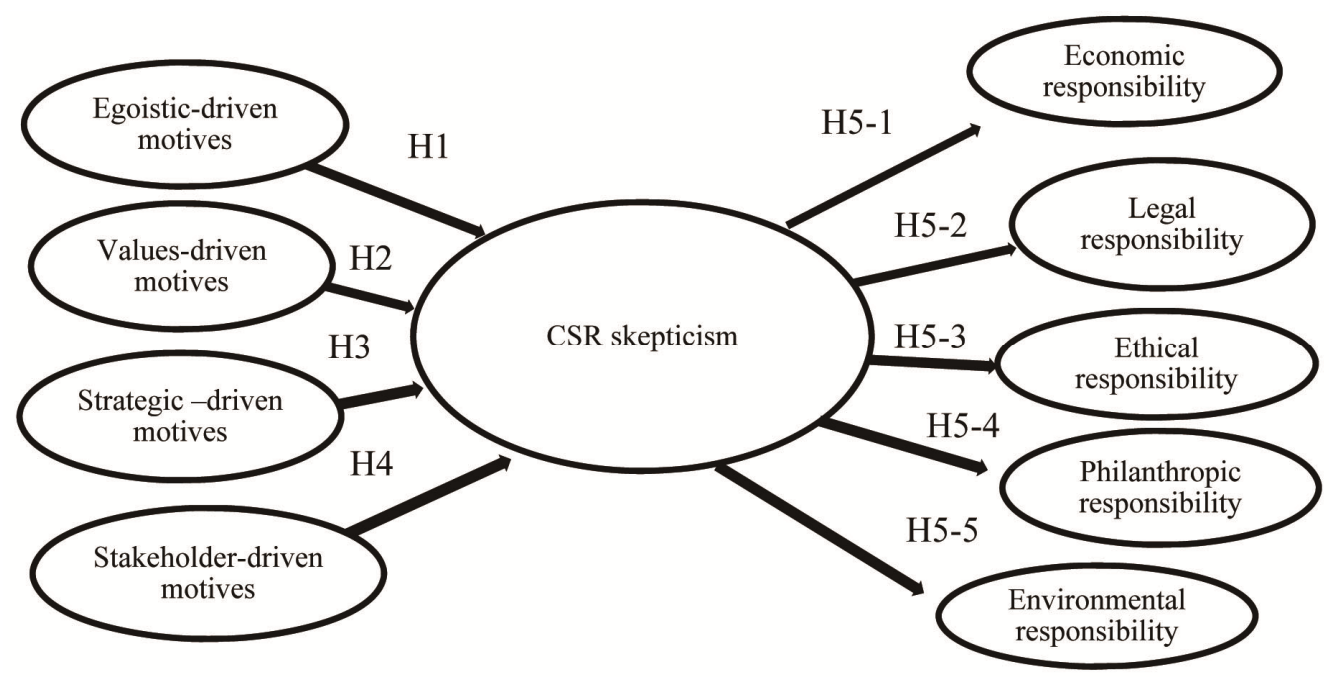

Figure 1. Proposed the framework of consumer attributions, consumer skepticism toward CSR, and perceived CSR

\section{Method}

\subsection{Sample and Data Collection}

This study aimed to explore the relationship of consumer attributions, consumer skepticism toward CSR, and its influence on perceived CSR. This study adapted survey instrument targeting finance students in Taiwan. Finance students were selected to be the target group was for several reasons. First, students could be suitable samples because college students have general consumer experience and behaviors (Donnelly, Ksendzova, \& Howell, 2013). Second, the consumers who support CRM are young and educated (Webb \& Mohr, 1998). The concept of creative CSR and global views of CSR are the abilities which students must possess and significant influences on society, economic, and environmental development (Chen, 2012). In addition, it is important to understand business students' perceptions because they will be the leaders in business circles (Mccabe, Butterfield, \& Trevino, 2006). Recently finance scandals occur and the effects are discussed in relevant courses so that finance students are familiar with CSR debate and the concept of CSR has become a crucial issue to teach in ethical courses. Hence, the participants of this study are finance students not only for students have buying behavior but for students could soak in CSR initiatives. Stratified cluster sampling method was used in this study. A list of 20 universities was chosen, and the participants were juniors and seniors at universities, located in northern, central, southern, and eastern Taiwan. A total of 1000 questionnaires were delivered to the finance office of every school 
and 788 questionnaires were received. However, 129 of these were excluded because the respondents did not rate the scenario provided as realistic. Thus, final usable questionnaires received from 659 respondents to reach the return rate of $78.8 \%$. A majority of the respondents have working experience. Table 1 lists the demographic characteristic of the sample.

Table 1. Demographic characteristics of the sample

\begin{tabular}{|c|c|c|c|}
\hline \multicolumn{2}{|l|}{ Variables } & Number & Percentage \\
\hline \multirow[t]{2}{*}{ Grade } & Junior & 443 & 67.2 \\
\hline & Senior & 216 & 32.8 \\
\hline \multirow[t]{2}{*}{ Gender } & Male & 264 & 40.1 \\
\hline & Female & 395 & 59.9 \\
\hline \multirow[t]{2}{*}{ School } & Public & 295 & 44.8 \\
\hline & Private & 364 & 55.2 \\
\hline \multirow[t]{2}{*}{ School sort } & Vocational & 162 & 24.6 \\
\hline & University & 497 & 75.4 \\
\hline \multirow[t]{4}{*}{ School location } & Northern district & 214 & 32.5 \\
\hline & Central district & 247 & 37.5 \\
\hline & Southern district & 173 & 26.3 \\
\hline & Eastern district & 25 & 3.8 \\
\hline \multirow[t]{2}{*}{ Work experience } & $\mathrm{Y}$ & 487 & 73.9 \\
\hline & $\mathrm{N}$ & 172 & 26.1 \\
\hline \multirow[t]{5}{*}{ Place of residence } & Northern district & 247 & 37.5 \\
\hline & Central district & 163 & 24.7 \\
\hline & Southern district & 204 & 31.0 \\
\hline & Eastern district & 23 & 3.5 \\
\hline & Outlying island & 22 & 3.3 \\
\hline
\end{tabular}

Note. $\mathrm{N}=659$.

\subsection{Measures}

All of the measures used in this study were adopted in the relevant literature, then modified and translated into Chinese in the context of the current study. A draft questionnaire was developed, and three academics whose background relate to CSR were invited to assess the content validity of the measures. A pilot test of 62 finance students was recruited to answer the preliminary questionnaire. The three sub-dimensions of consumer attributions, consumer skepticism toward CSR, and perceived CSR showed acceptable reliability (Cranbach alpha $=.865, .90$, and .888$)$ that exceeded Nunnnally's (1978) and Wu's (2011) value of 0.70 .

The current study applied a scenario and two items to test whether participants could image the situation and believe the scenario. Received responses excluded with a score lower than 2 for one of the two items. In addition, participants were shown a statement of CSR to deepen CSR sense. This study employed a 5-point Likert-type scale ranging from strongly disagree (1) to strongly agree (5). The construct of consumer attributions derived from Ellen et al. (2006), Vlachos et al. (2009), and Groza et al. (2011). Of the consumer attribution scales, three items were used to assess egoistic-driven motives, four items to assess values-driven motives, three items to assess strategic-driven motives, and three items to assess stakeholder-driven motives. The construct of consumer skepticism which measured using four items was adapted from Skarmeas \& Leonidou's (2013) work. Consumer skepticism toward CSR was operated to assess the extent to which the consumer is doubtful to CSR activities in which corporations engage. The construct of perceived CSR consist of five scales, including economic responsibility with three items, legal responsibility with four items, ethical responsibility with three items, philanthropic responsibility with four items, and environmental responsibility with three items was from previous works of Maignan (2001), Stanaland et al. (2011), and Lee et al. (2013).

\section{Results}

\subsection{Validity of the Measures}

Structural equation modeling (SEM) was utilized to test the proposed model and hypothesis paths. Exploratory factor analysis was conducted to examine the internal consistency of the measures. The resulting measures loaded in one single factor with Cronbach's alpha that exceeded the threshold of 0.7 (Nunnally, 1978). This study used maximum likelihood method to estimate the analysis. Next, confirmatory factor analysis using AMOS 21.0 assessed the convergent validity and discriminant validity of the items. Table 2 presents the results of the 
measurement model including factor loading, composite reliability (C.R.), and average variance extracted (AVE), Cronbach's alpha scores, mean, and standard deviation. All standardized factor loadings were larger than .5, most of which were larger than .7 (Hair et al., 1998). Composite reliability of the constructs was ranged between .74 and .905 , which larger than .7. Average variance extracted were greater than .5 except the constructs of economic responsibility (AVE $=.49$ ) and ethical responsibility $(\mathrm{AVE}=.49)$. Fornell \& Larcker (1981) concluded that the convergent validity is adequate if composite reliability is larger than .6, even though AVE of some constructs is lower than .5 , indicating a significant evidence of convergent validity.

Table 2. Measurement model results

\begin{tabular}{|c|c|c|c|c|c|c|c|}
\hline Construct & Items & $\begin{array}{l}\text { Standardized } \\
\text { loading }\end{array}$ & C.R. & AVE & Cronbach $\alpha$ & Mean & $\mathrm{SD}$ \\
\hline \multirow[t]{3}{*}{ Egoistic-driven motives } & EM1 & .740 & 0.830 & 0.620 & 0.828 & 3.22 & 0.89 \\
\hline & EM2 & .797 & & & & & \\
\hline & EM3 & .823 & & & & & \\
\hline \multirow[t]{4}{*}{ Values-driven motives } & VM1 & .799 & 0.874 & 0.635 & 0.874 & 3.15 & 0.85 \\
\hline & VM2 & .815 & & & & & \\
\hline & VM3 & .813 & & & & & \\
\hline & VM4 & .760 & & & & & \\
\hline \multirow[t]{3}{*}{ Strategic-driven motives } & SM1 & .670 & 0.802 & 0.576 & 0.826 & 3.44 & 0.79 \\
\hline & SM2 & .790 & & & & & \\
\hline & SM3 & .810 & & & & & \\
\hline \multirow[t]{3}{*}{ Stakeholder-driven motives } & SdM1 & .690 & 0.814 & 0.597 & 0.835 & 3.66 & 0.78 \\
\hline & $\mathrm{SdM} 2$ & .900 & & & & & \\
\hline & SdM3 & .710 & & & & & \\
\hline \multirow[t]{4}{*}{ CSR Skepticism } & CSRS1 & .860 & 0.904 & 0.702 & 0.905 & 3.08 & 0.87 \\
\hline & CSRS2 & .850 & & & & & \\
\hline & CSRS3 & .820 & & & & & \\
\hline & CSRS4 & .820 & & & & & \\
\hline \multirow[t]{3}{*}{ Economic responsibility } & EcR1 & .640 & 0.791 & 0.560 & 0.779 & 3.99 & 0.66 \\
\hline & EcR2 & .770 & & & & & \\
\hline & EcR3 & .823 & & & & & \\
\hline \multirow[t]{4}{*}{ Legal responsibility } & LR1 & .840 & 0.889 & 0.667 & 0.889 & 4.16 & 0.69 \\
\hline & LR2 & .870 & & & & & \\
\hline & LR3 & .820 & & & & & \\
\hline & LR4 & .730 & & & & & \\
\hline \multirow[t]{3}{*}{ Ethical responsibility } & EtR1 & .670 & 0.725 & 0.480 & 0.737 & 3.88 & 0.71 \\
\hline & EtR2 & .860 & & & & & \\
\hline & EtR3 & .500 & & & & & \\
\hline \multirow[t]{4}{*}{ Philanthropic responsibility } & PR1 & .800 & 0.832 & 0.557 & 0.826 & 3.98 & 0.67 \\
\hline & PR2 & .850 & & & & & \\
\hline & PR3 & .710 & & & & & \\
\hline & PR4 & .600 & & & & & \\
\hline \multirow[t]{3}{*}{ Environmental responsibility } & EnR1 & .630 & 0.822 & 0.612 & 0.809 & 4.06 & 0.68 \\
\hline & EnR2 & .920 & & & & & \\
\hline & EnR3 & .770 & & & & & \\
\hline
\end{tabular}

Note. C.R.: composite reliability, AVE: average variance extracted, SD: standard deviation.

\subsection{Hypotheses Testing}

Structural equation modeling was employed to test the hypotheses paths. The results of the measurement model indicated that confirmatory factor analysis provided an acceptable fit to the data: $\mathrm{X} 2=2383.59, \mathrm{p}<0.001$, $\mathrm{df}=$ 512; X2 /df = 4.655; Goodness of Fit Index $(\mathrm{GFI})=.784$; Adjusted-Goodness-of-Fit Index (AGFI) = .749; Root Mean Square Residual $(\mathrm{RMR})=.118$; Comparative Fit Index $(\mathrm{CFI})=.847$; Normed-Fit Index $(\mathrm{NFI})=.814$; Incremental Fit Index $($ IFI $)=.848$; Parsimonious Goodness-Fit-Index $(\mathrm{PGFI})=.675$; Non-Normed Fit Index $(\mathrm{NNFI})=.833$; Root Mean Square Error of Approximation $(\mathrm{RMSEA})=.075$.

Table 3 reveals the results of relationships of hypotheses paths. H1 posits value-driven motives are negatively related to CSR skepticism, which was not significant $(\beta=-.09, \mathrm{t}=-.389)$. Specifically, $\mathrm{H} 2$ proposes value-driven motives are negatively related to CSR skepticism, which was significant; however, the relationship was positive 
association $(\beta=.779, \mathrm{t}=15.171)$. H3 proposes strategic-driven motives are positively related to CSR skepticism, which was not significant $(\beta=.065, \mathrm{t}=1.255)$. Consistent with $\mathrm{H} 3$, stakeholder-driven motives are positively related to CSR skepticism was not supported $(\beta=.032, \mathrm{t}=.844)$. Also, H5-1, H5-2, and H5-5 were not supported, which propose CSR skepticism is negatively related economic responsibility $(\beta=.04, \mathrm{t}=.88$ ), positively related legal responsibility $(\beta=-.074, \mathrm{t}=-1.713)$, and positively related environmental responsibility $(\beta=.036, \mathrm{t}=.818)$. Finally, H5-3 proposes CSR skepticism is positively related to ethical responsibility, which was supported $(\beta=.107, \mathrm{t}=2.329)$. $\mathrm{H} 5-4$ posits $\mathrm{CSR}$ skepticism is negatively related to philanthropic responsibility, which was significant; however, the relationship was positive association.

Table 3. Results of hypotheses tests

\begin{tabular}{llll}
\hline Hypotheses paths & Standardized estimate & t-value & Test result \\
\hline H1: Egoistic-driven motives $\rightarrow$ CSR skepticism & -0.019 & -0.389 & Not supported \\
H2: Values-driven motives $\rightarrow$ CSR skepticism & 0.779 & $15.171^{* *}$ & Not supported \\
H3: Strategic-driven motives $\rightarrow$ CSR skepticism & 0.065 & 1.255 & Not supported \\
H4: Stakeholder-driven motives $\rightarrow$ CSR skepticism & 0.032 & 0.844 & Not supported \\
H5-1: CSR skepticism $\rightarrow$ Economic responsibility & 0.040 & 0.880 & Not supported \\
H5-2: CSR skepticism $\rightarrow$ Legal responsibility & -0.074 & -1.713 & Not supported \\
H5-3: CSR skepticism $\rightarrow$ Ethical responsibility & 0.107 & $2.329^{*}$ & Supported \\
H5-4: CSR skepticism $\rightarrow$ Philanthropic responsibility & 0.106 & $2.390^{*}$ & Not supported \\
H5-5: CSR skepticism $\rightarrow$ Environmental responsibility & 0.036 & 0.818 & Not supported \\
\hline
\end{tabular}

Note. ${ }^{*} \mathrm{p}<.05,{ }^{* *} \mathrm{p}<.01$

\subsection{Check for Common Method Variance}

Several methods helped to estimate common method variance (CMV). This study utilized Harman's single-factor test is to assess the measures, which is a general method to check the survey. The results of exploratory factor analysis was performed all the model variables accounted for $62.94 \%$ of the total variance, with average explaining $10.5 \%$ of the variance. The results indicated there was no significant influence of CMV.

\section{Discussion and Conclusions}

This study proposed a model of consumer attributions, consumer skepticism toward CSR, and its influence on perceived CSR in Taiwan. The hypotheses were tested using SEM. In conclusion, CSR skepticism is positively related to ethical responsibility and philanthropic responsibility. Meanwhile, value-driven motives are negatively related to CSR skepticism, which was significant. This study may make a positive contribution for business managers to understand the expectations of consumers in Taiwan.

\section{References}

Achabou, M. A., \& Dekhili, S. (2013). Luxury and sustainable development: Is there a match? Journal of Business Research, 66(10), 1896-1903. http://dx.doi.org/10.1016/j.jbusres.2013.02.011

Anuar, M. M., \& Mohamad, O. (2012). Effects of skepticism on consumer response toward cause-related marketing in Malaysia. International Business Research, 5(9), 98-105. https://doi.org/10.5539/ibr.v5n9p98

Becker-Olsen, K. L., Cudmore, B. A., \& Hill, R. P. (2006). The impact of perceived corporate social responsibility on consumer behavior. Journal of Business Research, 59(1), 46-53. https://doi.org/10.1016/j.jbusres.2005.01.001

Carroll, A. B. (1991). The pyramid of corporate social responsibility: Toward the moral management of $\begin{array}{lllll}\text { organizational } & \text { stakeholders. } & \text { Business } & \text { Horizons, } & 34(4),\end{array}$ https://doi.org/10.1016/0007-6813(91)90005-G

Carroll, A. B., \& Shabana, K. M. (2010). The business case for corporate social responsibility: A review of concepts, research and practice. International Journal of Management Review, 2010, 85-105. https://doi.org/10.1111/j.1468-2370.2009.00275.x

Coppa, M., \& Sriramesh, K. (2013). Corporate social responsibility among SMEs in Italy. Public Relations Review, 39(1), 30-39. https://doi.org/10.1016/j.pubrev.2012.09.009

Donnelly, G., Ksendzova, M., \& Howell, R. T. (2013). Sadness, identity, and plastic in over-shopping: The interplay of materialism, poor credit management, and emotional buying motives in predicting compulsive buying. Journal of Economic Psychology, 39, 113-125. https://doi.org/10.1016/j.joep.2013.07.006 
Ellen, P. S., Webb, D. J., \& Mohr, L. A. (2006). Building Corporate Associations: Consumer Attributions for Corporate Socially Responsible Programs. Journal of the Academy of Marketing Science, 34(2), 147-157. https://doi.org/10.1177/0092070305284976

Folse, J. A. G., Niedrich, R. W., \& Grau, S. L. (2010). Cause-Relating Marketing: The Effects of Purchase Quantity and Firm Donation Amount on Consumer Inferences and Participation Intentions. Journal of Retailing, 86(4), 295-309. http://dx.doi.org/10.1016/j.jretai.2010.02.005

Forehand, M. R., \& Grier, S. (2003). When Is Honesty the Best Policy The Effect of Stated Company Intent on Consumer Skepticism. Journal of Consumer Psychology, 13(3), 349-356. https://doi.org/10.1207/S15327663JCP1303_15

González-Rodríguez, M. R., Díaz-Fernández, M. C., Pawlak, M., \& Simonetti, B. (2012). Perceptions of students university of corporate social responsibility. Quality \& Quantity, 47(4), 2361-2377. https://doi.org/10.1007/s11135-012-9781-5

Grappi, S., Romani, S., \& Bagozzi, R. P. (2013). Consumer response to corporate irresponsible behavior: Moral emotions and virtues. Journal of Business Research, 66(10), 1814-1821. https://doi.org/10.1016/j.jbusres.2013.02.002

Grewal, D., Roggeveen, A. L., \& Tsiros, M. (2008). The Effect of Compensation on Repurchase Intentions in Service Recovery. Journal of Retailing, 84(4), 424-434. http://dx.doi.org/10.1016/j.jretai.2008.06.002

Grimmer, M., \& Bingham, T. (2013). Company environmental performance and consumer purchase intentions. Journal of Business Research, 66(10), 1945-1953. http://dx.doi.org/10.1016/j.jbusres.2013.02.017

Groening, C., \& Kanuri, V. K. (2013). Investor reaction to positive and negative corporate social events. Journal of Business Research, 66(10), 1852-1860. http://dx.doi.org/10.1016/j.jbusres.2013.02.006

Groza, M. D., Pronschinske, M. R., \& Walker, M. (2011). Perceived Organizational Motives and Consumer Responses to Proactive and Reactive CSR. Journal of Business Ethics, 102(4), 639-652.

Hair, J., Black, B., Babin, B., Anderson, R., \& Tatham, R. (2006). Multivariate data analysis. New Jersey: Pearson Prentice Hall.

Hsu, K. T. (2011). The Advertising Effects of Corporate Social Responsibility on Corporate Reputation and Brand Equity: Evidence from the Life Insurance Industry in Taiwan. Journal of Business Ethics, 109(2), 189-201. https://doi.org/10.1007/s10551-011-1118-0

Kucukusta, D., Mak, A., \& Chan, X. (2013). Corporate social responsibility practices in four and five-star hotels: Perspectives from Hong Kong visitors. International Journal of Hospitality Management, 34, 19-30. http://dx.doi.org/10.1016/j.ijhm.2013.01.010

Lai, C. S., Chiu, C. J., Yang, C. F., \& Pai, D. C. (2010). The Effects of Corporate Social Responsibility on Brand Performance: The Mediating Effect of Industrial Brand Equity and Corporate Reputation. Journal of Business Ethics, 95(3), 457-469. https://doi.org/10.1007/s10551-010-0433-1

Lee, E. M., Park, S. Y., \& Lee, H. J. (2012). Employee perception of CSR activities: Its antecedents and consequences. Journal of Business Research.

Lee, E. M., Park, S. Y., Rapert, M. I., \& Newman, C. L. (2012). Does perceived consumer fit matter in corporate social responsibility issues? Journal of Business Research, 65(11), 1558-1564. https://doi.org/10.1016/j.jbusres.2011.02.040

Lin-Hi, N., \& Müller, K. (2013). The CSR bottom line: Preventing corporate social irresponsibility. Journal of Business Research, 66(10), 1928-1936. https://doi.org/10.1016/j.jbusres.2013.02.015

Maignan, I. (2001). Consumers' perceptions of corporate social responsibilities: A cross-cultrual comparison. Journal of Business Ethics, 30, 57-72. https://doi.org/10.1023/A:1006433928640

Martínez, P., \& Rodríguez del Bosque, I. (2013). CSR and customer loyalty: The roles of trust, customer identification with the company and satisfaction. International Journal of Hospitality Management, 35(0), 89-99. http://dx.doi.org/10.1016/j.ijhm.2013.05.009

Mccabe, D. L., Butterfield, K. D., \& Trevino, L. K. (2006). Academic Dishonesty in Graduate Business Programs: Prevalence, causes, and proposed action. Academy of Management Learning \& Education, 5(3), 294-305. https://doi.org/10.5465/AMLE.2006.22697018

Murphy, P. E., \& Schlegelmilch, B. B. (2013). Corporate social responsibility and corporate social 
irresponsibility: Introduction to a special topic section. Journal of Business Research, 66(10), 1807-1813. https://doi.org/10.1016/j.jbusres.2013.02.001

Obermiller, C., \& Spangenberg, E. R. (1998). Development of a Scale to Measure Consumer Skepticism Toward $\begin{array}{lllll}\text { Advertising. Journal of } & \text { Consumer }\end{array}$ https://doi.org/10.1207/s15327663jcp0702_03

Peloza, J., \& Shang, J. (2011). How can corporate social responsibility activities create value for stakeholders? A systematic review. Journal of the Academy of Marketing Science, 39(1), 117-135. https://doi.org/10.1007/s11747-010-0213-6

Perks, K. J., Farache, F., Shukla, P., \& Berry, A. (2013). Communicating responsibility-practicing irresponsibility in CSR advertisements. Journal of Business Research, 66(10), 1881-1888. http://dx.doi.org/10.1016/j.jbusres.2013.02.009

Skarmeas, D., \& Leonidou, C. N. (2013). When consumers doubt, Watch out! The role of CSR skepticism. Journal of Business Research, 66(10), 1831-1838. https://doi.org/10.1016/j.jbusres.2013.02.004

Stanaland, A. J. S., Lwin, M. O., \& Murphy, P. E. (2011). Consumer Perceptions of the Antecedents and Consequences of Corporate Social Responsibility. Journal of Business Ethics, 102(1), 47-55. https://doi.org/10.1007/s10551-011-0904-z

Strike, V. M., Gao, J., \& Bansal, P. (2006). Being Good While Being Bad: Social Responsibility and the International Diversification of US Firms. Journal of International Business Studies, 37(6), 850-862. https://doi.org/10.1057/palgrave.jibs.8400226

Sweetin, V. H., Knowles, L. L., Summey, J. H., \& McQueen, K. S. (2013). Willingness-to-punish the corporate brand for corporate social irresponsibility. Journal of Business Research. https://doi.org/10.1016/j.jbusres.2013.02.003

Varadarajan, P. R., \& Menon, A. (1988). Cause-Related Marketing: A Coalignment of Marketing Strategy and Corporate Philanthropy. Journal of Marketing, 52(3), 58-74. https://doi.org/10.2307/1251450

Vlachos, P. A., Tsamakos, A., Vrechopoulos, A. P., \& Avramidis, P. K. (2009). Corporate social responsibility: attributions, loyalty, and the mediating role of trust. Journal of the Academy of Marketing Science, 2009(37), 170-180. https://doi.org/10.1007/s11747-008-0117-x

Wagner, T., Bicen, P., \& Hall, Z. R. (2008). The dark side of retailing: towards a scale of corporate social irresponsibility. International Journal of Retail \& Distribution Management, 36(2), 124-142. https://doi.org/10.1108/09590550810853075

Webb, D. J., \& Mohr, L. A. (1998). A Typology of Consumer Responses to Cause-Related Marketing: From Skeptics to Socially Concerned. Journal of Public Policy \& Marketing, 17(2), 226-238.

\section{Copyrights}

Copyright for this article is retained by the author, with first publication rights granted to the journal.

This is an open-access article distributed under the terms and conditions of the Creative Commons Attribution license (http://creativecommons.org/licenses/by/4.0/). 